\title{
The Role of Magnesium Ions in the Growth of Salmonella Phage Anti-R
}

\author{
BY R. G. TUCKER* \\ British Empire Cancer Campaign Unit for Virus Research, Sir William Dunn \\ School of Pathology, University of Oxford, and Microbiology Unit, \\ Department of Biochemistry, University of Oxford
}

(Received 28 March 1961)

\begin{abstract}
SUMMARY
Magnesium or certain other divalent metal ions are needed for the adsorption of phage anti-R to its host, a 'rough' strain of Salmonella typhi. In medium containing magnesium ions the infected organisms burst after a latent period of about $20 \mathrm{~min}$. at $37^{\circ}$, but when infected organisms are diluted into medium without added divalent metal ions phage growth is considerably inhibited. A rapid increase in phage titre occurs when magnesium ions are added late, i.e. at some time after the end of the normal latent period, to dilute cultures of phage-infected organisms. During the interval between infection and this late addition of magnesium ions no appreciable numbers of infective intracellular phage were detected after ultrasonic disruption of the organisms. It is concluded that in addition to being an adsorption cofactor, magnesium functions at some late stage in phage development. Phage anti-R is probably related to $\Phi \mathbf{X} 174$; it consists of particles approximately $30 \mathrm{~m} \mu$ in diameter and the intact phage reacts similarly with formaldehyde.
\end{abstract}

\section{INTRODUCTION}

Many phages require divalent metal ions for growth or fail to act on their specific bacterial hosts in the presence of substances such as sodium citrate and sodium oxalate which bind these ions (see Fildes, Kay \& Joklik, 1952). Phage reproduction may be dependent upon divalent metals in a variety of ways. Some phages are unstable in the free state unless metal ions, particularly calcium, are present (Adams, 1949); some are unable to attach to the host in the absence of the ions (Gratia, 1940), and others need the ions to facilitate the entry of phage nucleic acid (Luria \& Steiner, 1954). Fildes (1954) established that calcium or magnesium ions are needed for the activity of salmonella phage anti-R (A. 59/6 SR Felix). The following paper describes further experiments on the divalent metal requirement of this phage, with special reference to the action of $\mathrm{Mg}^{++}$.

\section{METHOD}

Host organism. Phage anti-R is active on 'rough' strains of Salmonella typhi and on some strains of Escherichia coli. In the work to be described, S. typhi R4 derived from NCTC no. 3390 (Kay \& Fildes, 1950), was used as the host organism,

* Present address: Microbiology Unit, Department of Biochemistry, University of Oxford. 
stock cultures being maintained at $4^{\circ}$ on slopes of tryptic meat agar and subcultured monthly.

Media. Medium A contained $1 \%$ (w/v) peptone (Evans), $7 \cdot 5 \times 10^{-2} \mathrm{M}-\mathrm{NaCl}$ and $2 \times 10^{-3} \mathrm{M}-\mathrm{MgSO}_{4}$. Medium B was the chemically defined medium of Kay \& Fildes (1950) used at half strength. Before use it was supplemented with $2 \times 10^{-2} \mathrm{M}$-glucose and $0.05 \%(\mathrm{w} / \mathrm{v})$ decalcified peptone (Fildes, 1954).

Phage. There is some doubt about the precise origin of phage anti-R but it is thought to have been isolated from a patient with paratyphoid $\mathbf{A}$ fever. The large size of the plaques formed by the phage suggests that it is very small (Elford \& Andrewes, 1932) and this is confirmed by electron micrographs which show that it consists of apparently tailless particles about $30 \mathrm{~m} \mu$ in diameter.

Phage assay. The standard double-layer plate method was used (Adams, 1950). The layers consisted of medium A solidified with $2 \%$ (w/v) agar (Difco) over which a mixture of $2 \mathrm{ml}$. melted agar medium (medium A containing $1.25 \%, \mathrm{w} / \mathrm{v}$, agar) and $1 \mathrm{ml}$. host + phage mixture was poured. All phage estimations were done in duplicate. After overnight incubation at $37^{\circ}$ plaques of $5 \mathrm{~mm}$. average diameter were formed. This size limited the number of discrete plaques that could be accommodated on a $9 \mathrm{~cm}$. diameter Petri dish and the usual procedure was to incubate the assay plates at $37^{\circ}$ for $3 \mathrm{hr}$. and then to remove them to room temperature (about $20^{\circ}$ ) overnight. In this way plaques of $2 \mathrm{~mm}$. average diameter, easily discernible against the bacterial background, were formed. There was a linear relation between numbers of plaques and concentration of phage suspension plated up to about 300 plaques/Petri dish.

Preparation of phage suspensions. An initial stock of phage was prepared by three successive single-plaque isolations and inoculation of the last of them into an actively growing culture of Salmonella typhi $\mathbf{R} 4$ in medium $\mathbf{A}$ which was aerated in shaken $\perp$-shaped tubes (Monod, Cohen-Bazire \& Cohn, 1951) at $37^{\circ}$. When lysis was completed the cell debris was removed by centrifugation and the supernatant fluid decanted into a screw-capped bottle containing a drop of chloroform. Larger volumes of phage suspension were made by inoculating actively growing cultures of $S$. typhi $\mathrm{R} 4$ at about $10^{8}$ organisms $/ \mathrm{ml}$. in medium $\mathrm{A}$ with one-tenth the number of phage. The cultures were aerated vigorously for $3 \mathrm{hr}$. either in conical flasks attached to a reciprocating mechanical shaker or in rotating flasks (Mitchell, 1949). The cell debris sedimented by centrifugation at $2000 \mathrm{~g}$ retained a considerable amount of phage and this could be partially recovered by suspending the debris in $3 \cdot 3 \times 10^{-2} \mathrm{M}$ phosphate buffer $\left(10 \cdot 1 \mathrm{~g} . \mathrm{Na}_{2} \mathrm{HPO}_{4} \cdot 12 \mathrm{H}_{2} \mathrm{O}+0 \cdot 68 \mathrm{~g} . \mathrm{KH}_{2} \mathrm{PO}_{4} / \mathrm{l} \cdot ; \mathrm{pH} 7 \cdot 6\right)$ and shaking for a further hour before again centrifuging at $2000 \mathrm{~g}$. The supernatant fluids from both centrifugations were pooled and gave phage titres that varied from $2 \times 10^{9}$ to $1 \times 10^{10}$ plaque forming units (pfu)/ml. Higher titre phage stocks (up to $2 \times 10^{11}$ $\mathrm{pfu} / \mathrm{ml}$.) were made by alternate cycles of low-speed $(\mathbf{2 0 0 0} \mathrm{g}$ ) centrifugation and high-speed $(105,000 \mathrm{~g})$ centrifugation in a Spinco model $\mathrm{L}$ ultracentrifuge using $3.3 \times 10^{-2} \mathrm{M}$-phosphate buffer $(\mathrm{pH} 7 \cdot 6)$ containing $0.01 \%(\mathrm{w} / \mathrm{v})$ serum albumin as the suspending medium.

Measurement of phage adsorption. Fresh cultures of Salmonella typhi $\mathrm{R} 4$ grown tó $10^{9}$ organisms $/ \mathrm{ml}$. in medium $\mathrm{A}$ at $37^{\circ}$ were centrifuged and the bacteria washed once with $3.3 \times 10^{-2} \mathrm{M}$-phosphate buffer $(\mathrm{pH} \mathbf{7 \cdot 6})$. Before use the organisms were resuspended in the original culture volume of buffer and further diluted into buffer with or without added divalent metals. After equilibrating $9 \mathrm{ml}$. bacterial suspen- 
sion at $37^{\circ}$ for 10 min., $1 \mathrm{ml}$. phage suspension containing about $10^{5} \mathrm{pfu} / \mathrm{ml}$. was added and rapidly mixed. Samples taken at intervals were diluted 10 -fold into icecold $3 \cdot 3 \times 10^{-2} \mathrm{M}$-phosphate buffer $(\mathrm{pH} 7 \cdot 6$ ) and quickly assayed for phage before and after centrifugation at $2000 \mathrm{~g}$ to sediment bacteria and adsorbed phage.

One-step growth experiments. Nine ml. medium B inoculated with $1 \mathrm{ml}$. of an overnight culture of Salmonella typhi $\mathrm{R} 4$ in the same medium were aerated in a $\perp$-tube at $37^{\circ}$ to give about $1.5 \times 10^{8}$ organisms $/ \mathrm{ml}$. The culture was concentrated by centrifugation and resuspension of the organisms in $1 \mathrm{ml}$. of the supernatant fluid. Magnesium sulphate $\left(0 \cdot 1 \mathrm{ml} ., 4 \times 10^{-2} \mathrm{M}-\mathrm{MgSO}_{4}\right)$ and phage anti-R $(0 \cdot 1 \mathrm{ml}$. of a suspension containing about $2 \times 10^{10} \mathrm{pfu} / \mathrm{ml}$.) were added and the mixture incubated in stationary culture at $37^{\circ}$ for $10 \mathrm{~min}$. At the end of this adsorption period $9 \mathrm{ml}$. ice-cold medium $\mathbf{B}$ were added and the organisms sedimented in a cooled centrifuge tube. The bacteria were washed once with $10 \mathrm{ml}$. ice-cold medium, centrifuged, and after resuspension, diluted into medium $B$ at $37^{\circ}$. The final dilution was aerated in a $\perp$-tube at $37^{\circ}$ and assayed for phage at intervals. Compared with one-step growth experiments in which the infected culture was not washed, the latent period was not greatly lengthened by this procedure, provided the time between the addition of ice-cold medium and the final dilution into warmed medium was discounted. The method decreased the free phage to less than $1 \%$ of the initial count.

Determination of intracellular phage. The organisms in samples taken during onestep growth experiments were disrupted by one of two methods. The first involved incubation for $90 \mathrm{~min}$. at $37^{\circ}$ in a lysing mixture containing $2.5 \mathrm{M}$-glycine and $10^{-2} \mathrm{M}-\mathrm{KCN}$ (Kay, 1952). Preliminary experiments showed that the turbidity of either uninfected or phage anti-R-infected Salmonella typhi R 4 was decreased more than $85 \%$ after $2-3 \mathrm{hr}$. incubation in the lysing mixture at $37^{\circ}$, and that the decrease in titre of a phage suspension maintained for $3 \mathrm{hr}$. in the mixture at $37^{\circ}$ was no greater than that of a control suspension in buffer incubated similarly.

The second method used ultrasonic vibration (Anderson \& Doermann, 1952). Potassium cyanide to a final concentration of $10^{-2} \mathrm{M}$ was added to prevent further phage growth and the samples were then treated for 5 min. in a Mullard Ultrasonic Generator, Type E 7590B (Mullard Ltd., London). This period of ultrasonic vibration decreased the viability of a dilute suspension of Salmonella typhi R 4 to $2 \%$ of the initial count, but periods of ultrasonic treatment as long as $20 \mathrm{~min}$. of dilute phage suspensions did not decrease their titre.

Bacterial counts. The method of Miles \& Misra (1938) was used. For routine purposes the number of organisms in a culture was assessed turbidimetrically by using a curve relating counts to the opacities of cultures in medium B in a Hilger 'Spekker' Absorptiometer (Hilger \& Watts Ltd., London, N.W. 1).

Spectrophotometry. A Unicam SP 500 Spectrophotometer (Unicam Instruments Ltd., Cambridge) was used with cuvettes of $1 \mathrm{~cm}$. light path.

\section{RESULTS}

\section{The stability of phage anti-R}

Phage lysates which had been diluted into $3 \cdot 3 \times 10^{-2} \mathrm{M}$-phosphate buffer ( $\mathrm{pH} \mathrm{7 \cdot 6}$ ) and maintained at $37^{\circ}$ in unshaken test tubes lost about $20 \%$ of their initial titre in $90 \mathrm{~min}$. This inactivation was not appreciably diminished by the addition to the 
diluent of $\mathrm{MgSO}_{4}\left(4 \times 10^{-3} \mathrm{M}\right), \mathrm{CaCl}_{2}\left(5 \times 10^{-4} \mathrm{M}\right)$ or Na citrate $\left(10^{-2} \mathrm{M}\right)$. Some of the diluted phage suspensions showed a delayed inactivation which was best seen at an elevated temperature $\left(50^{\circ}\right)$. This delay and the inability to obtain phage titres greater than about $10^{10} \mathrm{pfu} / \mathrm{ml}$. in multistep lysates, in spite of average burst size of 500 in one-step growth experiments in medium A, suggested that some phage may be masked either by aggregation or by reversible inactivation by material present in the lysates. Even after several cycles of alternate low-speed and high-speed centrifugation the concentrated phage suspension still produced a precipitate when incubated with bacterial antiserum, and flagellar material derived from the host bacterium could be seen in electron micrographs of phage prepared in this way. Whenever possible, concentrated phage preparations treated with bacterial antiserum were used for the subsequent experiments, though there was evidence from the occasional variation in the titre of certain stocks that the cause of the masking was not entirely eliminated by antiserum treatment.

\section{The effect of divalent metal ions on the attachment of phage anti- $\boldsymbol{R}$ to host bacteria}

There was no adsorption of phage anti-R to washed suspensions of Salmonella typhi $\mathbf{R} 4$ in $3.3 \times 10^{-2} \mathrm{M}$-phosphate buffer $(\mathrm{pH} 7 \cdot 6)$ at $37^{\circ}$ unless $\mathrm{Mg}^{++}$or other divalent metal ions were present. In the presence of excess bacteria about $90 \%$ of the initial phage input was adsorbed at an exponential rate which was proportional to the concentration of bacteria over the range $2 \times 10^{8}$ to $8 \times 10^{8}$ organisms $/ \mathrm{ml}$. The variation of the rate of adsorption of phage with $\mathrm{Mg}^{++}$and other divalent metal ions is shown in Fig. 1. The rates are calculated on the assumption that the adsorption of phage anti-R behaves as a first order reaction (Ellis \& Delbrück, 1939).

\section{The effect of divalent metal ions on the stages following attachment}

The stage immediately after attachment. The study of the function of divalent metals in the penetration of phage anti-R nucleic acid and in other early stages of the growth cycle was made difficult by the requirement of the metals for adsorption. Puck, Garen \& Cline (1951) found with phage T1 that there were two stages in the adsorption to Escherichia coli and that the second step was inhibited at low temperatures. With the usual method of measuring phage anti-R adsorption there appeared to be very little attachment at $0^{\circ}$ even in the presence of concentrations of $\mathrm{Mg}^{++}$that were effective at $37^{\circ}$. When, however, a comparison is made of the free phage in a host-phage mixture at $0^{\circ}$ both before and after dilution it is evident that although attachment occurred at $0^{\circ}$ in the presence of $\mathrm{Mg}^{++}$, it was reversible, unlike that at $37^{\circ}$ (Table 1).

Advantage was taken of the temperature sensitivity of permanent adsorption to determine whether it, like reversible attachment, is cation dependent. If it is, dilution into medium at $37^{\circ}$ of dissociable host-phage complexes that had been formed at $0^{\circ}$ should result in the elution of phage unless the medium contains added divalent metal ions. The results of this experiment (Table 2) show that transfer to medium not containing added $\mathrm{Mg}^{++}$but otherwise favourable for phage growth caused bound phage to be released.

Later stages of the phage-growth cycle. If divalent cations function only during the initial stages of the phage-growth cycle their removal once these have been 


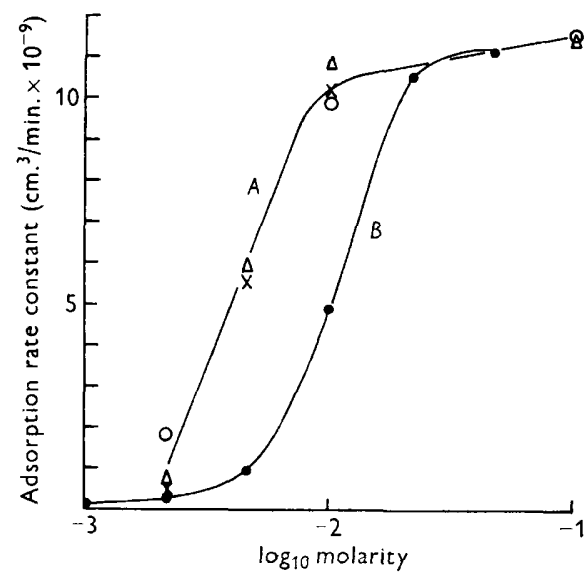

Fig. 1

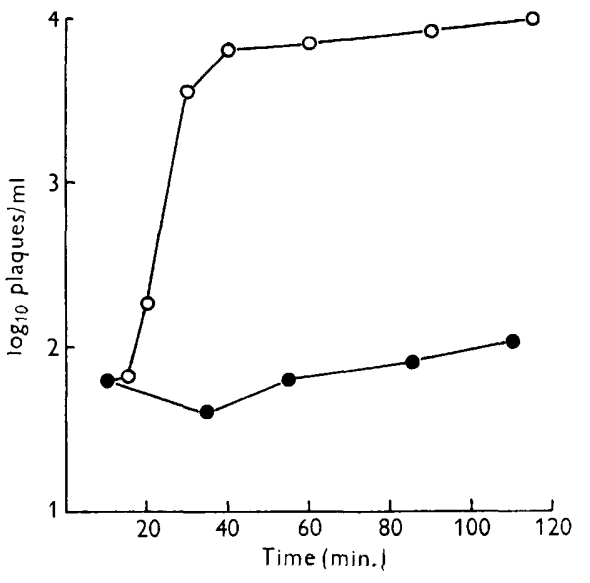

Fig. 2

Fig. 1. Effect of divalent metal ion concentration on the rate of adsorption of phage anti$\mathbf{R}$ to washed suspensions of Salmonella typhi $\mathbf{R} 4$. Curve $A$ : rates of adsorption in $3 \cdot 3 \times 10^{-4}$ M-phosphate buffer (pH 7.6) containing, $\mathrm{MgSO}_{4}, O ; \mathrm{CaCl}_{2}, \triangle ; \mathrm{SrCl}_{2}, \times$. Curve $\mathrm{B}$ : rates of adsorption in $3.3 \times 10^{-2} \mathrm{M}$-phosphate buffer $(\mathrm{pH} 7 \cdot 6)$ containing $\mathrm{MgSO}_{4}, 0$. Temperature $37^{\circ}$.

Fig. 2. Effect of $\mathrm{Mg}^{++}$on the growth of phage anti-R. Salmonella typhi $\mathbf{R} 4$ was infected with phage anti-R in the presence of $4 \times 10^{-3} \mathrm{M}-\mathrm{MgSO}_{4}$. The culture was diluted $1 / 10^{6}$ in medium $B$ after 10 min., then finally diluted 10 -fold into medium B, without $(-1)$, and with $(\mathrm{O}-\mathrm{O})$ added $\mathrm{MgSO}_{4}\left(10^{-8} \mathrm{M}\right)$. Temperature $37^{\circ}$.

completed should not affect the subsequent development of the phage. In onestep growth experiments the removal of $\mathrm{Mg}^{++}$after as long as $10 \mathrm{~min}$. at $37^{\circ}$ had a marked inhibitory effect on the burst size. Compared with the average burst size of about 100 in medium $\mathrm{B}$ containing $10^{-3} \mathrm{M}-\mathrm{MgSO}_{4}$ there was either a decrease or at most a very slight increase in plaque-forming centres when phage anti- $R$ infected organisms were diluted into medium $\mathrm{B}$ with no added $\mathrm{Mg}^{++}$(Fig. 2). Under the latter conditions there was in fact an increase in free phage, probably due to the trace amounts of divalent metals in medium $B$. The transfer of phage-infected bacteria to medium $\mathrm{B}$ supplemented with $\mathrm{Na}$ citrate $\left(10^{-2} \mathrm{M}\right)$ caused a decline in the number of plaque forming centres and no increase in free phage.

\section{Table 1. Reversibility of adsorption of phage anti-R at $0^{\circ}$}

Phage anti-R was added to a suspension of Salmonella typhi $\mathrm{R} 4$ in $3 \cdot 3 \times 10^{-2} \mathrm{M}-$ phosphate buffer (pH 7.6) containing $6 \times 10^{-3} \mathrm{M}-\mathrm{MgSO}_{4}$ and distributed into two tubes; (A) for incubation at $37^{\circ}(B)$ for incubation at $0^{\circ}$. After $3 \mathrm{~min}$. and $15 \mathrm{~min}$., respectively, two samples were removed from both tubes. One sample was centrifuged immediately and the supernatant fluid diluted in buffer before assay; the other was diluted into ice-cold buffer and assayed after centrifugation at the times indicated.

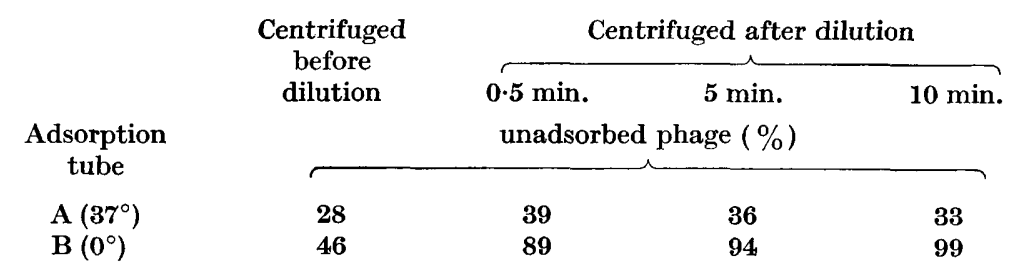


Table 2. Effect of $\mathrm{Mg}^{++}$on the second stage of adsorption

\begin{abstract}
Phage-anti-R was added to a culture of Salmonella typhi $\mathrm{R4}$ in medium B containing $4 \times 10^{-3} \mathrm{M}^{-\mathrm{MgSO}_{4}}$ at $0^{\circ}$. After $15 \mathrm{~min}$. there was $41 \%$ free phage in a sample centrifuged prior to dilution. Two further samples were then diluted 1/200 in medium $B$ with and without added $4 \times 10^{-3} \mathrm{M}-\mathrm{MgSO}_{4}$ at $37^{\circ}$. The adsorption was determined at intervals by assay before and after centrifugation.
\end{abstract}

$\begin{array}{ccc}\begin{array}{c}\text { Time after } \\ \begin{array}{c}\text { 1/200 dilution } \\ \text { (min.) }\end{array}\end{array} & \begin{array}{c}\text { No added } \\ \text { divalent } \\ \text { metal } \\ \text { Unadsorbed phage (\%) }\end{array} & \begin{array}{c}\text { With } \\ 4 \times 10^{-3} \mathrm{M}-\mathrm{MgSO}_{4}\end{array} \\ 0.25 & \overbrace{01} & - \\ 0.75 & - & 46 \\ 1.5 & 90 & - \\ 3 \cdot 0 & 100 & - \\ 3.5 & - & 42 \\ 7 \cdot 0 & - & - \\ 8.5 & 100 & 48\end{array}$

The point of action of divalent metals in the post-adsorptive stage

A culture of Salmonella typhi $\mathbf{R} 4$ in medium $\mathbf{B}$ was infected with phage anti-R and after $10 \mathrm{~min}$. was diluted into a $\perp$-tube containing medium $\mathrm{B}$ supplemented with $10^{-3} \mathrm{M}-\mathrm{MgSO}_{4}$. This culture was aerated at $37^{\circ}$ and at various times samples were diluted 10-fold into tubes of medium $\mathrm{B}$ containing $10^{-3} \mathrm{M}-\mathrm{MgSO}_{4}$ and into tubes of medium $\mathrm{B}$ containing $10^{-2} \mathrm{M}-\mathrm{Na}$ citrate. The phage content of the latter series of tubes was determined immediately and both sets of tubes were assayed after $90 \mathrm{~min}$. incubation at $37^{\circ}$. The results (Table 3) show that however late in the growth cycle the infected organisms were transferred to medium deficient in ionized magnesium there was no further increase in phage titre. These results indicated that magnesium ions functioned at some step at the end of the phage development cycle. Further evidence for this came from experiments in which infected bacteria placed in medium $\mathrm{B}$ without added $\mathrm{Mg}^{++}$were transferred at various times beyond the normal

\title{
Table 3. Effect of dilution into medium containing $\mathrm{Na}$ citrate on the growth of phage anti-R
}

A phage-infected culture of Salmonella typhi $\mathbf{R} 4$ was diluted into medium B containing $10^{-3} \mathrm{M}-\mathrm{MgSO}_{4}$ and incubated at $37^{\circ}$. Samples were removed at intervals and diluted 10 -fold into tubes of medium B containing $10^{-2} \mathrm{M}-\mathrm{Na}$ citrate (Series 1 ) and into tubes of medium B containing $10^{-3} \mathrm{M}_{-} \mathrm{MgSO}_{4}$ (Series 2 ). Series 1 was assayed immediately and both series were assayed after incubation for $90 \mathrm{~min}$. at $37^{\circ}$.

Initial After 90 min. incubation at $37^{\circ}$

$\begin{array}{crrr}\begin{array}{c}\text { Time after } \\ \begin{array}{c}\text { adding phage } \\ \text { (min.) }\end{array}\end{array} & \text { Series 1 } & \text { Series 1 } & \text { Series 2 } \\ & \overbrace{15}^{\text {Plaque count }} \\ 18 & 311 & 71 & 20,200 \\ 21 & 398 & 133 & 20,400 \\ 26 & 1,310 & 1,130 & 22,000 \\ 30 & 7,040 & 7,350 & 23,700 \\ 35 & 13,700 & 13,700 & 20,700 \\ & 18,800 & 15,600 & 21,500\end{array}$


end of the latent period (20 min.) to medium B supplemented with divalent metal ions. Figure 3 shows that the late addition of $\mathbf{M g}^{++}$produces a rapid increase in phage titre. The magnitude of the burst became less the longer the addition of $\mathrm{Mg}^{++}$ was delayed (Fig. 4).

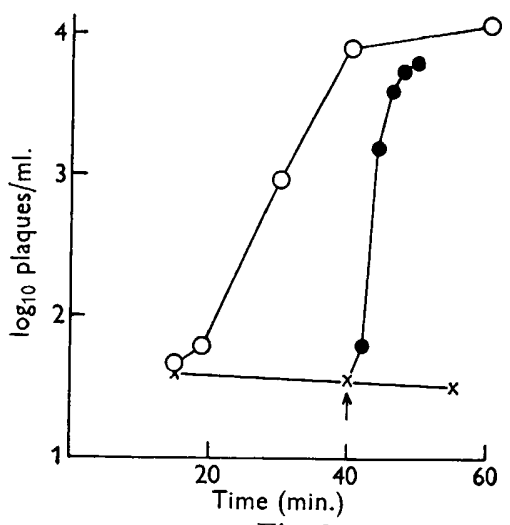

Fig. 3

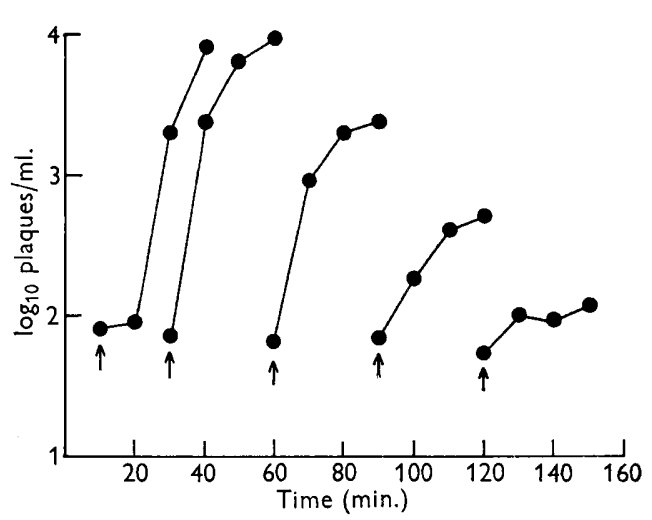

Fig. 4

Fig. 3. Effect of delayed addition of $\mathrm{Mg}^{++}$on the growth of phage anti-R. A culture of Salmonella typhi $\mathrm{R} 4$ in medium B containing $4 \times 10^{-3} \mathrm{M}-\mathrm{MgSO}_{4}$ was infected with phage anti-R and then diluted into medium $\mathrm{B}$, with $\mathrm{MgSO}_{4}, 10^{-3} \mathrm{M}(\mathrm{O}-\mathrm{O})$; and without added $\mathrm{Mg}^{++}(\times-\times)$. At $40 \mathrm{~min}$. a sample from the latter growth tube was transferred to another tube containing added $\mathrm{MgSO}_{4}$ (final concentration $10^{-3} \mathrm{M}$ ) (-) ( Temperature $37^{\circ}$.

Fig. 4. Effect of delayed addition of $\mathrm{Mg}^{++}$on phage anti-R growth. A culture of Salmonella typhi $\mathrm{R} 4$ in medium $\mathrm{B}$ containing $4 \times 10^{-3} \mathrm{M}-\mathrm{MgSO}_{4}$ was infected with phage anti-R and diluted into five 1 -tubes containing medium $B$ only. At the times indicated by the arrows $\mathrm{MgSO}_{4}$ (final concentration $10^{-3} \mathrm{M}$ ) was added to each of the tubes. Temperature $37^{\circ}$.

\section{The nature of the late metal-dependent step in phage anti- $R$ growth}

The only well-recognized stage at the end of the phage-growth cycle is the lytic reaction whereby fully mature phage particles inside the infected host are released into the medium. To ascertain whether or not divalent metals were cofactors for lysis a concentrated culture of Salmonella typhi R4 was infected with a 10-fold excess of phage anti-R in the presence of $10^{-3} \mathrm{M}-\mathrm{MgSO}_{4}$ at $37^{\circ}$. After $10 \mathrm{~min}$. the culture was diluted with cold medium $B$, centrifuged, washed with cold medium and finally resuspended in the initial volume of medium $\mathbf{B}$ without added $\mathbf{M g}^{++}$. Nine $\mathrm{ml}$. of the suspension were added to two $\perp$-tubes, one of which contained $1 \mathrm{ml}$. $4 \times 10^{-2} \mathrm{M}_{-} \mathrm{MgSO}_{4}$ and the other $1 \mathrm{ml}$. water. The tubes were shaken at $37^{\circ}$ and opacity readings were taken at intervals. Phage assays were made at the beginning and at the end of the experiment. The results (Fig. 5) showed that the decrease in turbidity of the cultures was independent of $\mathrm{Mg}^{++}$, though there was no rise in phage titre unless $\mathrm{Mg}^{++}$was present. Similar experiments in which the degree of lysis was determined by the amount of ultraviolet-absorbing material released into the supernatant fluid of infected cultures with or without added $\mathrm{Mg}^{++}$again showed that there was no difference in the degree of cell disruption.

\section{Intracellular growth of phage anti-R}

Attempts to show intracellular phage development by glycine + cyanide lysis method (Kay, 1952) were unsuccessful in spite of the good macroscopic lysis pro- 
duced when either suspensions of uninfected organisms or those infected with phage anti-R were added to the lysing medium of $2.5 \mathrm{M}$-glycine $+10^{-2} \mathrm{M}-\mathrm{KCN}$. The failure to detect intracellular phage by this method may be due to chelation of divalent metals by the high concentration of glycine (Albert, 1950). Thus intracellular phage could be shown if samples were added to a mixture of $10^{-2} \mathrm{M}-\mathrm{KCN}+10^{-3} \mathrm{M}_{-} \mathrm{MgSO}_{4}$ but not when added to a mixture of $10^{-2} \mathrm{M}-\mathrm{KCN}+10^{-2} \mathrm{M}-\mathrm{Na}$ citrate. By using ultrasonic vibration to disrupt phage-infected bacteria which had been diluted into medium $\mathbf{B}$ with added $\mathbf{M g}^{++}$it was possible to show that intracellular phage was formed before the bacteria lysed. In similar experiments in which infected organisms were diluted into medium $\mathrm{B}$ without added $\mathrm{Mg}^{++}$there was little increase in the phage content of sonicated or control samples until divalent metal was added (Fig. 6).

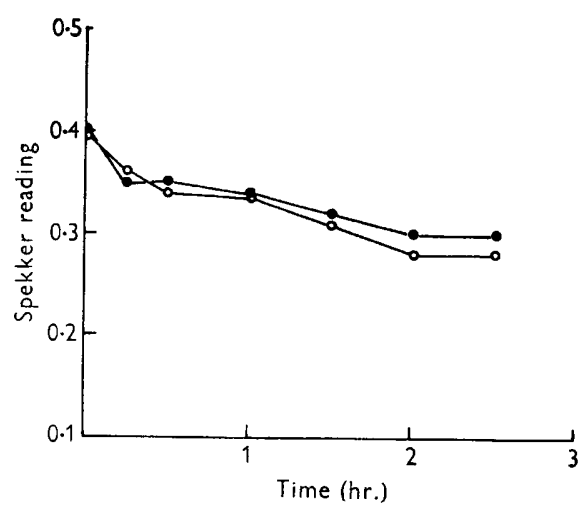

Fig. 5

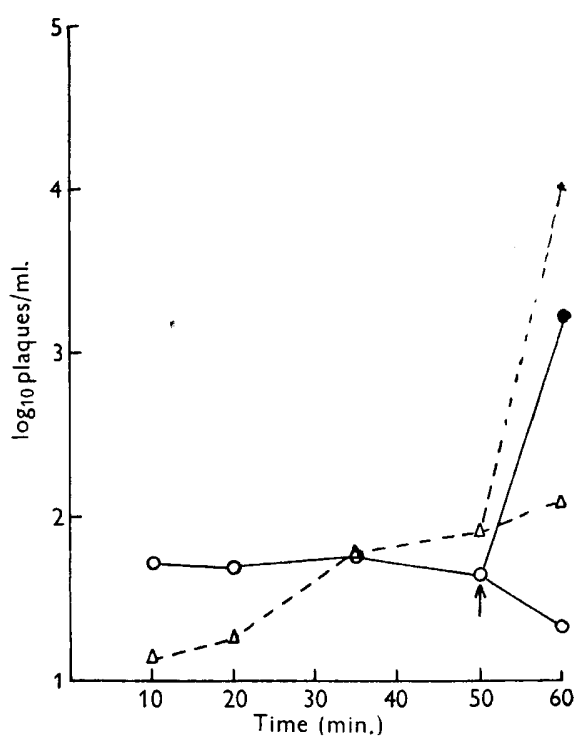

Fig. 6

Fig. 5. Effect of $\mathrm{Mg}^{++}$on the lysis of Salmonella typhi $\mathbf{R 4}$ by phage anti-R. A culture of $S$. typhi R4 was infected with phage anti-R and after washing was resuspended in medium $\mathrm{B}$, without added $\mathrm{Mg}^{++},(\mathrm{O}-\mathrm{O})$; and with added $\mathrm{MgSO}_{4}$ (final concentration $\left.4 \times 10^{-3} \mathrm{M}\right)$, (-O). Both cultures were aerated at $37^{\circ}$. Initial phage titre $=9 \times 10^{6} / \mathrm{ml}$. Final phage titre; without added $\mathrm{Mg}^{++}=10^{6} / \mathrm{ml}$.; with $\mathrm{Mg}^{++}\left(4 \times 10^{-3} \mathrm{M}\right)=2 \times 10^{8} / \mathrm{ml}^{\text {. }}$

Fig. 6. Effect of $\mathrm{Mg}^{++}$on the intracellular development of phage anti-R. A culture of Salmonella typhi $\mathrm{R} 4$ in medium B containing $4 \times 10^{-3} \mathrm{M}_{-} \mathrm{MgSO}_{4}$ was infected with phage anti-R and then diluted into medium $\mathbf{B}$ without added $\mathbf{M g}^{++}$. Samples were plated at intervals, before ultrasonic treatment $\left(\mathrm{O}^{-} \mathrm{O}\right)$ and after $5 \mathrm{~min}$. ultrasonic treatment $(\triangle \cdots-\triangle)$. At 50 min. a portion of the culture was transferred to a tube containing $\mathrm{MgSO}_{4}$ (final concentration $10^{-3} \mathrm{M}$ ) and at $60 \mathrm{~min}$. this was plated before ultrasonic treatment (-O-) and after 5 min. ultrasonic treatment (- $\Delta-)$. Temperature $37^{\circ}$.

\section{The relation of phage anti-R to phages $S 13$ and $\Phi X 174$}

The small size of phage anti-R particles suggested that the phage might be related to other small phages e.g. S13 and $\Phi$ X 174 and like them contain a characteristic type of nucleic acid (Sinsheimer, 1959). Concentrated preparations of phage anti-R were treated with host bacterial antiserum and then taken through a further 
cycle of low-speed and high-speed centrifugation. The final suspension of the phage was made in $10^{-2} \mathrm{M}$-phosphate buffer $(\mathrm{pH} \mathrm{7.0})$ and contained $4.5 \times 10^{11} \mathrm{pfu} / \mathrm{ml}$. The phage was diluted 10 -fold into $10^{-2} \mathrm{M}$-phosphate buffer containing $1 \cdot 6 \%(\mathrm{w} / \mathrm{v})$ formaldehyde and the absorption spectrum was measured immediately and after 1 , 6 and $23 \mathrm{hr}$. incubation at $37^{\circ}$. The results (Fig. 7) show that treatment with formaldehyde caused an increase in the extinction in the $260 \mathrm{~m} \mu$ region, with a shift in the absorption maximum to a greater wavelength. This reaction is one of the characteristics of single-stranded DNA (Sinsheimer, 1959). Other investigations (D. Kay, to be published) have shown that the nucleic acid isolated from phage anti-R has a composition which is indicative of single stranded DNA and that the intact phage differs immunologically from phage S13.

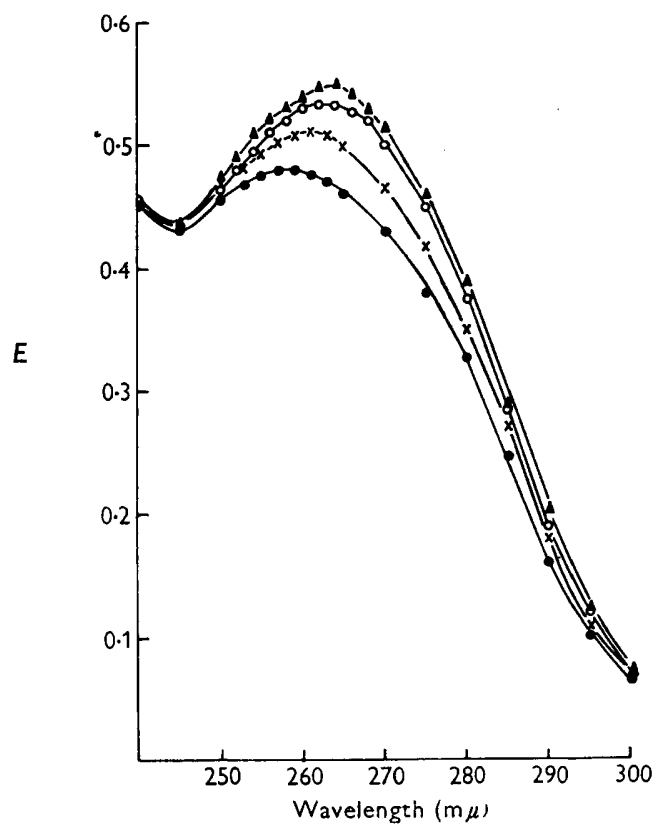

Fig. 7. Effect of formaldehyde on the absorption spectrum of phage anti-R. A suspension of phage anti-R treated with host bacterial antiserum was resuspended in $10^{-2} \mathrm{M}$-phosphate buffer (pH $7 \cdot 0)$ and diluted into the same buffer containing $1 \cdot 6 \%(\mathrm{w} / \mathrm{v})$ formaldehyde. Absorption spectrum measured at zero time $(\bullet-0) ; 1 \mathrm{hr} .(\times-x) ; 6 \mathrm{hr}$. (O-O) and $23 \mathrm{hr}$. ( $\Delta-\Delta)$. Temperature $37^{\circ}$.

\section{DISCUSSION}

The divalent metal requirement for the growth of phage anti-R, a small phage which may contain single-stranded DNA, can be satisfied by magnesium, calcium or strontium ions, and while the effect of $\mathrm{Mg}^{++}$alone has been investigated in detail the other cations must be presumed to act in a manner that is at least qualitatively the same. The promotion of phage anti- $\mathbf{R}$ adsorption by $\mathbf{M g}^{++}$is similar to the action of divalent cations on many other host-phage systems. Puck, Garen \& Cline (1951) measured the attachment of phage $\mathrm{T} 1$ to Escherichia coli $\mathrm{B}$ in the presence of different concentrations of alkaline earth metal ions and found that the optimum rate of adsorption was obtained at $5 \times 10^{-4} \mathrm{M}$ irrespective of the metal used. Mag- 
nesium, calcium and strontium ions function equally well as cofactors for the adsorption of phage anti-R to suspensions of Salmonella typhi $\mathbf{R} 4$ in buffer, and the rate of adsorption approaches a maximum at the highest concentration $\left(10^{-1} \mathrm{M}\right)$ investigated. The fastest rate of adsorption of phage anti-R is considerably greater than the maximum for phage T1 (Puck et al. 1951; Garen, 1954) but it is not inconsistent with the small size of the phage anti-R particle.

Adsorption at $0^{\circ}$ showed that infection by phage anti-R, like that by phage $\mathbf{T} 1$, involves two early reactions, the second of which is temperature-sensitive and leads to the permanent attachment of phage to host bacterium. The need for divalent metal ions for this second step prevented examination of the metal dependence of stages which follow rapidly upon attachment.

Decreasing the concentration of $\mathrm{Mg}^{++}$in the medium for a period as long as $10 \mathrm{~min}$. after adding phage anti-R greatly decreased the burst size and there was evidence for some action of the metal at a late stage of the growth cycle. First, removal of divalent cations by chelation during the rising phase of the burst prevented further increase in the phage titre. Such a result would be expected if $\mathrm{Mg}^{++}$or the other ions acted as cofactors for lysis. This could not be shown by direct measurement of changes in turbidity or by the estimation of ultraviolet-absorbing material released by infected organisms with or without added divalent cations; but it should be pointed out that the experimental conditions were somewhat different from those used previously and did not produce marked clearing even when divalent metals were present. Secondly, the addition of $\mathrm{Mg}^{++}$to infected bacteria in low-metal medium at a time well beyond the end of the normal latent period led to a rapid appearance of infective particles. The speed with which the plaque count increased seems to exclude an action on the multiplication of the phage and the result might also be explained as an action of $\mathrm{Mg}^{++}$on the lytic process. However, the inability to detect appreciable amounts of intracellular phage in organisms in low-metal medium suggests that the metals do function in some process which either leads to phage maturation or is necessary for the maintenance of intracellular phage in an infective state. Rountree (1955) described a calcium-dependent function occurring late during the growth cycle of certain staphylococcal phages. Although the nature of the function was not determined, it appeared in that case to be connected with intracellular stabilization of the phage rather than lysis, since chelation of the metals did not entirely prevent the subsequent liberation of some phage.

I wish to record my appreciation of the encouragement and helpful advice given by Sir Paul Fildes, F.R.S. Part of the work was done during the tenure of a Beit Memorial Fellowship, and work done at the Department of Biochemistry, Oxford, was aided by grants from the Rockefeller Foundation and the United States Department of Health, Education and Welfare.

\section{REFERENCES}

Adams, M. H. (1949). The stability of bacterial viruses in solutions of salts. J. gen. Physiol. 32, 579.

Adams, M. H. (1950). Methods of study of bacterial viruses. Meth. Med. Res. 11, 1.

AlBert, A. (1950). Quantitative studies of the activity of naturally occurring substances for trace metals. I. Amino acids having only two ionizing groups. Biochem. J. 47, 531 . 
Anderson, T. F. \& Doermann, A. H. (1952). The intracellular growth of bacteriophages. II. The growth of $\mathbf{T} 3$ studied by sonic disintegration and by $\mathbf{T} 6$-cyanide lysis of infected cells. J. gen. Physiol. 35, 657.

Elford, W. J. \& Andrews, C. H. (1932). The sizes of different bacteriophages. Brit. J. exp. Path. 13, 446.

Elurs, E. L. \& Delbrück, M. (1939). The growth of bacteriophage. J. gen. Physiol. 22, 365.

Findes, P. (1954). The relation of divalent metals to lysis of typhoid bacilli by bacteriophages. Brit. J. exp. Path. 35, 122.

Frldes, P., KAY, D. \& JokLIK, W. K. (1952). Divalent metals in phage production. Symp. Soc. gen. Microbiol. 2, 194.

Garen, A. (1954). Thermodynamic and kinetic studies on the attachment of $T 1$ bacteriophage to bacteria. Biochem. biophys. Acta, 14, 163.

Gratia, A. (1940). Action des électrolytes sur les bactériophages et sur leur fixation par les bactéries sensibles. Bull. Acad. Med. Belg. 5, 232.

KAY, D. (1952). The intracellular multiplication of coli bacteriophage T5st. Brit. J. exp. Path. 33, 236.

KAY, D. \& Findes, P. (1950). The calcium requirement of a typhoid bacteriophage. Brit. J. exp. Path. 31, 338.

Luria, S. E. \& Steiner, D. L. (1954). The role of calcium in the penetration of bacteriophage T5 into its host. J. Bact. 67, 635 .

Miles, A. A. \& Misra, S. S. (1938). The estimation of the bactericidal power of the blood. J. Hyg., Camb. 38, 732.

Mitchell, P. (1949). A new technique for stirred aerated culture. Nature, Lond. 164, 846.

Monod, J., Cohen-Bazire, G. \& Cohn, M. (1951). Sur la biosynthèse de la $\beta$-galactosidase (lactase) chez Escherichia coli. La specificité de l'induction. Biochem. biophys. Acta, 7, 585.

Puck, T. T., Garen, A. \& Cline, J. (1951). The mechanism of virus attachment to host cells. I. The role of ions in the primary reaction. J. exp. Med. 93, 65 .

Rountree, P. M. (1955). The role of divalent cations in the multiplication of staphylococcal bacteriophages. J. gen. Microbiol. 12, 275.

Sinsheimer, R. L. (1959). Purification and properties of bacteriophage $\Phi$ X 174 . J. mol. Biol. 1, 37. 